\title{
A STUDY TO IDENTIFY HYDROGEN MASER FAILURE MODES:
}

\author{
A. E. Popa, H. T.M. Wang, W.B. Bridges, A.N. Chester, J.E. Etter, and B. L. Walsh \\ Hughes Research Laboratories \\ Malibu Canyon Road \\ Malibu, California 90265
}

\section{Summary}

Technical problem areas are presented that may adversely affect the reliability of extended spaceborne operation of a hydrogen maser frequency standard in the Navstar Global Positioning System. Included are failures that have occurred in past maser designs even though such failures are now understood and could be circumvented in future designs. It is concluded that all the failure mechanisms are amenable to space qualification engineering. The greatest potential problem areas are dissociator stability and atom production, storage bulb lifetime in a space radiation environment, and radiation damage to the electronics subsystem, particularly sensors.

\section{Introduction}

This study was undertaken to identify technical problem areas that may adversely affect the reliability of spaceborne operation of a hydrogen maser frequency standard in the Navstar Global Positioning System (GPS). From this analysis of existing maser designs, areas for design improvement can be identified.

In this paper we attempt to list all possible failure mechanisms that may occur in both spaceborne and ground-based hydrogen masers. Included are failures that have occurred in past maser designs, even though such failures are now understood and could be circumvented in future designs.

\section{Physics Unit Failure Modes}

Tables 1 and 2 list the various components that comprise the physics unit of a hydrogen maser. Associated with each component or element are one or more modes of failure that have been observed in past maser designs or that we project as possibilities for a spaceborne maser design. For each failure mode several possible causes are listed; the asterisks indicate known chronic cases.

Hydrogen supply and regulation components are low risk items because of the past experience with similar space-qualified gas supply systems. Careful engineering of the final hardware design is all that is required here.

Difficulties with the rf discharge plasma hydrogen dissociator have been common in the past, but recent experience has improved typical operating life to three or more years. Figure 1 is a schematic representation of a typical spherical glass bulk dissociator plasma with capacitively coupled electrodes. The power is fed into the bulb by displacement current through the glass walls to the conducting hydrogen plasma within.

\footnotetext{
* This work was supported by the Naval Research Laboratories under Contract N00014-75-C-1149. Robert B. Moore, Scientific Officer.

*** Hughes Aircraft Company, Space and Communications Group, P. O. Box 92919, Los Angeles, CA 90009 .
}

Table 1. Principal Failure Modes Physics Unit (1)

\begin{tabular}{|c|c|c|}
\hline COMPONENT & FAILURE MODE & POSSIBLE MECHANISM \\
\hline $\mathrm{H}_{2}$ SUPPLY & LOSS OF $\mathrm{H}_{2}$ FLOW CONTROL & $\begin{array}{l}\text { VALVE HEATER BURN-OUT } \\
\text { PRESSURE SENSOR } \\
\text { MALFUNCTION } \\
\text { CONTROL SYSTEM FAULT } \\
\text { GAS LEAK } \\
\text { POWER LOSS } \\
\end{array}$ \\
\hline \multirow[t]{2}{*}{ DISSOCIATOR } & DISCHARGE CEASES & $\begin{array}{l}\text { "IMPEDANCE CHANGE THRU } \\
\text { CONTAMINATION } \\
\text { "WALL EROSION } \\
\text { RF DRIVER FAILS } \\
\text { CONTROL CIRCUIT FAILS } \\
\text { POWER LOSS }\end{array}$ \\
\hline & $\begin{array}{l}\text { H ATOM PRODUCTION } \\
\text { DECLINES ("WHITES OUT") }\end{array}$ & $\begin{array}{l}\text { "WALL RECOMBINATION } \\
\text { GAS CONTAMINATION } \\
\text { "WALL SPUT TERING } \\
\text { SERVO CONTROL FAILURE }\end{array}$ \\
\hline COLLIMATOH & $\begin{array}{l}\text { DECREASED THROUGHPUT } \\
\text { OF COLLIMATED ATOMS }\end{array}$ & $\begin{array}{l}\text { MECHANICAL CRACKING } \\
\text { WALL EROSION } \\
\text { WALL CONTAMINATION } \\
\text { CAUSING RECOMBINATION } \\
\text {-MISALIGNMENT }\end{array}$ \\
\hline STATE SELECTOR & $\begin{array}{l}\text { DECREASED THROUGHPUT } \\
\text { OF FOCUSSED ATOMS }\end{array}$ & $\begin{array}{l}\text { LOSS OF POLE STRENGTH } \\
\text { MISALIGNMENT }\end{array}$ \\
\hline
\end{tabular}

Table 2. Principal Failure Modes Physics Unit (2)

\begin{tabular}{|c|c|c|}
\hline COMPONENT & FAILURE MOOE & POSSIBLE MECHANISM \\
\hline STORAGE BULB & $\begin{array}{l}\text { LOSS OF SIGNAL AND/OR } \\
\text { STABILITY }\end{array}$ & $\begin{array}{l}\text { "OECREASED STORAGE TIME BY } \\
\text { TEFLON IRRADIATION DAMAGE } \\
\text { "CHANGE IN WALL SHIFT BY } \\
\text { RADIATION DAMAGE } \\
\text { "MECHANICAL FRACTURE MIS- } \\
\text { ALIGNMENT DURING LAUNCH } \\
\text { MICROWAVE LOSSES DUE TO } \\
\text { BULB IRRADIATION }\end{array}$ \\
\hline MICAOWAVE CAVITY & $\begin{array}{l}\text { LOSS OF SIGNAL AND/OR } \\
\text { STABILITV }\end{array}$ & $\begin{array}{l}\text { LOSS OF CAVITY O THRU COATING } \\
\text { SEPARATION } \\
\text { STRESSES ON CAVITY }\end{array}$ \\
\hline ION PUMP & LOSS OF VACUUM & $\begin{array}{l}\text { "MECHANICAL STRESS (TI HYDRIDE) } \\
\text { "HIGH VOLTAGE SHORTS (ZEROG) }\end{array}$ \\
\hline VACUUM SYSTEM & LOSS OF VACUUM & $\begin{array}{l}\text { OUTGASSING } \\
\text { VIRTUAL LEAKS } \\
\text { DISCHARGE SPUT TERING }\end{array}$ \\
\hline MAGNETIC SHIELOING & LOSS OF STABILITY & $\begin{array}{l}\text { EXCESSIVE EXTERNAL MAGNETIC } \\
\text { INTERFERENCE }\end{array}$ \\
\hline $\begin{array}{l}\text { THERMAL } \\
\text { SUBSYSTEM }\end{array}$ & $\begin{array}{l}\text { LOSS OF TEMPERATURE } \\
\text { UNIFORMITY OR } \\
\text { STABILITY* }\end{array}$ & $\begin{array}{l}\text { POWER LOSS } \\
\text { •AGING OF THERMAL SENSORS } \\
\text { CONTROL CIRCUIT FAILURE } \\
\text { STRESS-INDUCED MECHANIC^L } \\
\text { FRACTURE }\end{array}$ \\
\hline $\begin{array}{l}\text { MAGNETIC FIELD } \\
\text { AND DEGAUSSING } \\
\text { COILS }\end{array}$ & LOSS OF STABILITY & $\begin{array}{l}\text { COIL BURN OUT } \\
\text { CONTROL CIRCUIT FAILURE } \\
\text { POWER LOSS }\end{array}$ \\
\hline
\end{tabular}

Figure 2 illustrates the potential distribution near the glass walls, showing the potential fall or "wall sheath" necessary to satisfy boundary conditions on wall current. The wall sheath has the effect of increasing the energy with which positive ions strike the wall; this, in turn, greatly increases the yield of wall material sputtered by the incident ions. Figure 3 shows the typical steep dependence of sputtering yield 
on ion energy for the low energies typical of the wall sheath. Only a one or two volt change in wall sheath can cause an order of magnitude change in the sputtered material yield.

The improvements in dissociator bulb life observed empirically in recent years can probably be attributed to

- Increase in bulb size

- Better coupling into the plasma

- Lower drive power.

These three factors serve to decrease the displacement current density through the walls and decrease the energies of the ions incident on the bulb walls. Further improvement may be possible by further changes in configuration and choice of wall materials.

While the multitube glass collimators themselves have exhibited little difficulty, mechanical strains in the region adjacent to the collimator often produce problems in conventional designs. Careful attention to mechanical design and vacuum interlocks that prevent large transient pressure differentials across the collimator bundle during startup should eliminate this potential failure point.

No areas of high risk are associated with the maser state selector magnet.

The principal potential cause of failure resulting from the hydrogen storage bulb is degradation of the Teflon (C) coatings from the space radiation environment. Increased recombination rates will occur if the fluorine bonds are broken to produce more chemically active sites. Microcracks in the coating which expose the underlying $\mathrm{SiO}_{2}$ will also increase the probability of recombination. Changes in the wall shift may be produced by radiation, although this has not been documented experimentally. We have performed dose calculations on a typical maser design in the Navstar GPS orbit and have obtained values of 7000 rads ( $T f$ ) for seven years in the natural background and 18,000 rads $(\mathrm{T} f)$ if a nuclear event is added. These values are known experimentally not to cause any gross degradation of Teflon. (C)

A spaceborne maser development program will require accelerated radiation testing to determine if any wall shift and linewidth changes occur for the radiation dose encountered in the Navstar orbit. We have found $x$-ray diffraction measurements can detect slight changes in Teflon $(\mathrm{C}$ ) below the threshold of gross radiation damage. For example, thin Teflon (C) solar cell covers exposed to doses several times greater than that encountered by Navstar show a development of crystallinity as illustrated in Fig. 4. Whether changes observed by $x$-ray diffraction will correlate with degradation in maser performance remains to be determined.

The microwave cavity structure offers small failure risk. Substantial weight savings through the use of advanced composite materials technology will indirectly contribute to the reliability of the entire maser by reducing structural stresses.

The ion vacuum pump is a well-developed component. However, a zero-g environment of fers the potential hazard of free-floating particles which can short the high voltage elements. Special attention to

(C)is DuPont trademark. mechanical design will be required to keep stresses caused by conversion of titanium to titanium hydride from creating distortions that would short out internal electrodes.

Of the remaining components in Table 1 , only the thermal sensors are likely to be a problem in the spaceborne maser design. Calibration drift with radiation dose or thermal cycling will have to be investigated carefully.

\section{Electronics Unit Failure Modes}

All electronic subsystems are subject to failure mechanisms that are generally well known. Thermal fatigue, chemical diffusion, and electromigration are particular hazards for devices dissipating high power, while contamination and corrosion, shorts (from loose metallic particles) and bond failures are encountered by all electronic components.

In Table 3 the principal failure modes for the hydrogen maser electronics unit are listed. The highest risk is as sociated with space-radiation damage and inadequate thermal sinking of the higher power solid state devices. In the past, point contact devices, such as Schottky mixers, have been subject to contact failure in vibration; however, recent work at Hughes and other laboratories has produced techniques to greatly reduce the occurrence of this potentially serious problem. Many electronic problems can be eliminated by careful inspection as shown in the Scanning Electron Microscope (SEM) pictures, Figs. 5,6 , and 7 . Figure 5 is a mechanically stable Schottky diode whisker contacting a gold electrode imbedded in the semiconductor surface. Figure 6 shows a blunted whisker that has mechanically moved off the gold electrode causing a failure. The SEM picture shown in Fig. 7 graphically illustrates the result of electromigration. In this case potassium contamination left from wafer processing has migrated to the whisker causing diode failure.

Table 3. Principal Failure Modes Electronics Unit (3)

\begin{tabular}{|c|c|c|}
\hline COMPONENT & FAILURE MODE & POSSIBLE MECHANISM \\
\hline CRYSTAL OSCILLATOR & $\begin{array}{l}\text { EXCESSIVE FREQUENCY } \\
\text { AGING } \\
\text { LOSS OF SIGNAL }\end{array}$ & $\begin{array}{l}\text { +RADIATION DAMAGE } \\
\text { TO QUARTZ } \\
\text { VIBRATION INDUCED } \\
\text { FRACTURES } \\
\end{array}$ \\
\hline SYNTHESIZER & DEGRADED STABILITY & $\begin{array}{l}\text { RADIATION DAMAGE TO } \\
\text { JUNCTIONS }\end{array}$ \\
\hline VARACIOR & $\begin{array}{l}\text { OEGRADED OUTPUT } \\
\text { SIGNAL LEVEL }\end{array}$ & $\begin{array}{l}\text { RADIATION DAMAGE } \\
\text { INCREASES REVERSE } \\
\text { LEAKAGE CURRENT }\end{array}$ \\
\hline MIXERS & $\begin{array}{l}\text { DEGRADED NOISE } \\
\text { FIGURE } \\
\text { LOSS OF SIGNAL }\end{array}$ & $\begin{array}{l}\text {-RAOIATION OAMAGE } \\
\text { INCREASES SERIES } \\
\text { RESISTANCE } \\
\text { POINT CONTACT FAILURE } \\
\text { IN VIBRATION } \\
\end{array}$ \\
\hline $\begin{array}{l}\text { DISSOCIATOR } \\
\text { DRIVER AND POWER } \\
\text { OSCILLATORS }\end{array}$ & $\begin{array}{l}\text { OUTPUT POWER } \\
\text { OEGRADATION }\end{array}$ & -THERMAL AGING \\
\hline
\end{tabular}

\section{Conclusions}

Although there are many difficult problem areas that may adversely affect the reliability of a long lived spaceborne hydrogen maser frequency standard, all a re amenable to space qualification engineering. We feel the greatest potential problem areas at present are 
- Dissociator stability and atom production

- Storage bulb lifetime in a space radiation environment

- Radiation damage to the electronics subsystem components, pazticularly sensor 8 .

\section{Acknowledgments}

We began our hydrogen maser studies by visiting a number of organizations a ctive in the maser field and related activities. Specifically, we would like to acknowledge contributions from the following groups: H.E. Peters (NASA, retired) and V.S. Reinhardt at the NASA Goddard Space Flight Center; N. F. Ramsey and D. Larson at Harvard University: our own divisions at Hughes Aircraft Company working in related areas of technology; $R$. Sydnor and P. Dachel at the Jet Propulsion Laboratory of California Institute of Technology: R. L. Easton, V. Folen, and R.B. Moore at the Naval Research Laboratories: H. Hellwig and $F$. Walls of the Boulder Laboratories of NBS: R.F. C. Vessot and M. W. Levine at Smithsonian Astrophysical Observatory; and S. B. Crampton and H. T.M. Wang (now with Hughes Research Laboratories) at Williams College.

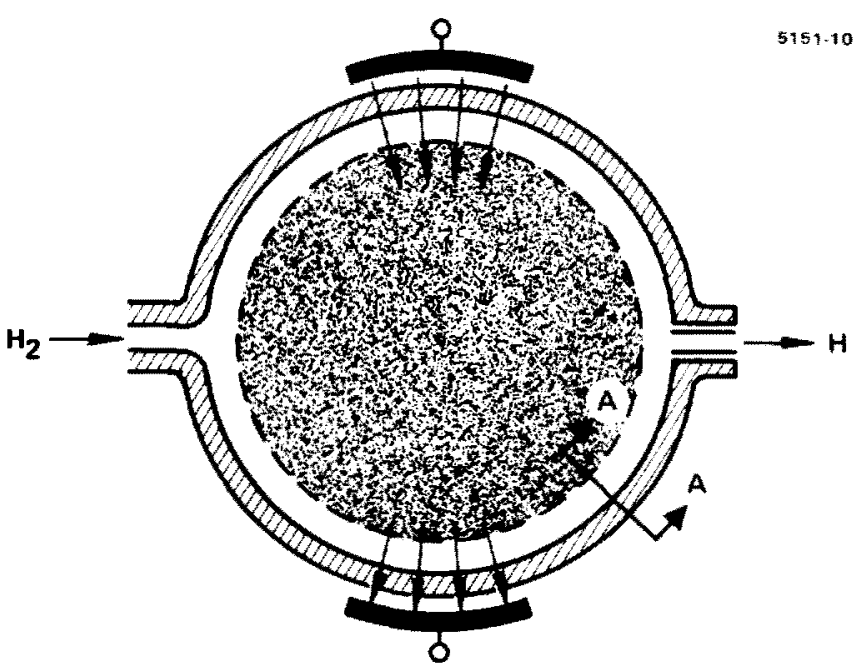

Fig. 1.

Schematic representation of the plasma within an if excited dissociator showing displacement current through the walls under the electrodes.

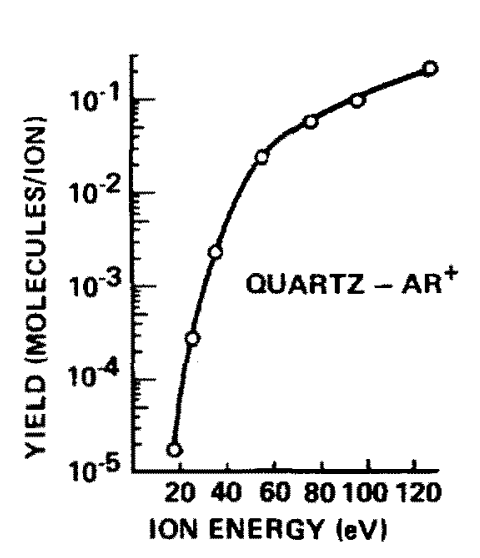

Fig. 3.

Sputtering yield of $\mathrm{SiO}_{2}$ molecules from a $\mathrm{SiO}_{2}$ surface under bombardment of low energy argon ions.



Fig. 4. X-ray diffraction pattern of radiation-damage Teflon solar cell covers. 


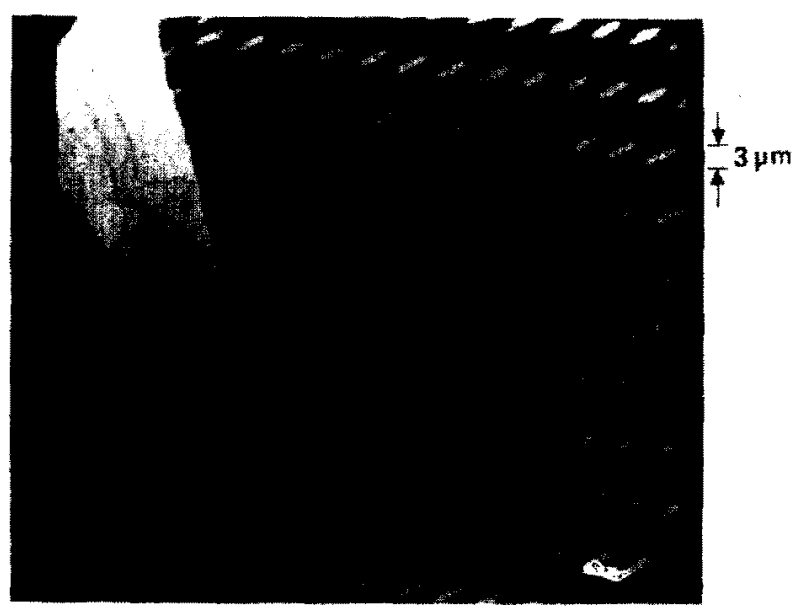

Fig. 5. SEM of a mechanically stable Schottky point contact.



Fig. 6. SEM of a blunted Schottky diode point contact that has mechanically failed.

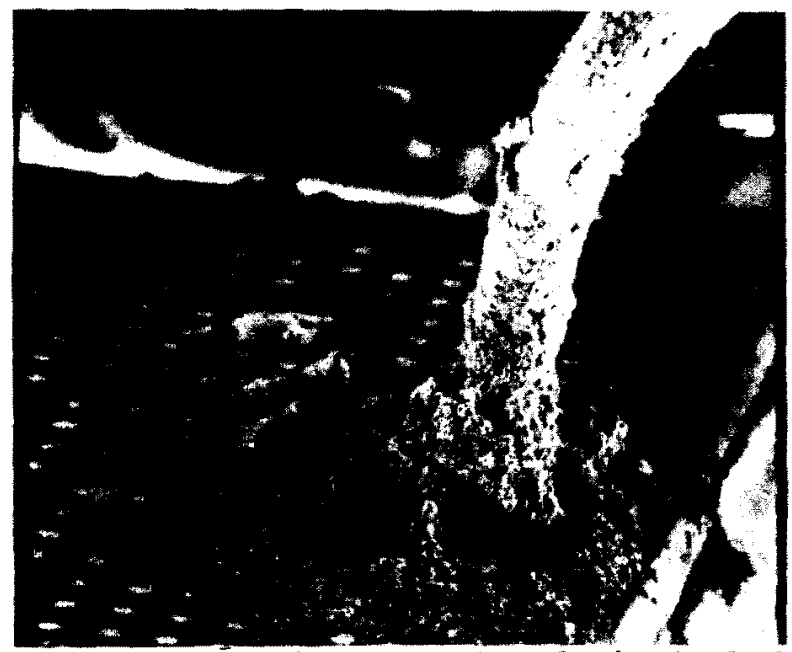

Fig. 7. SCM of a potassium contaminated Schottky diode illustrating the electromigration process. 